IZA DP No. 646

\title{
The Return of the Long-Run Phillips Curve
}

\author{
Liam Graham \\ Dennis J. Snower
}

November 2002 


\title{
The Return of the Long-Run Phillips Curve
}

\author{
Liam Graham \\ Birkbeck College, University of London \\ Dennis J. Snower \\ Birkbeck College, University of London, \\ CEPR and IZA Bonn
}

\section{Discussion Paper No. 646 \\ November 2002}

\author{
IZA \\ P.O. Box 7240 \\ D-53072 Bonn \\ Germany \\ Tel.: +49-228-3894-0 \\ Fax: +49-228-3894-210 \\ Email: iza@iza.org
}

This Discussion Paper is issued within the framework of IZA's research area Welfare State and Labor Market. Any opinions expressed here are those of the author(s) and not those of the institute. Research disseminated by IZA may include views on policy, but the institute itself takes no institutional policy positions.

The Institute for the Study of Labor (IZA) in Bonn is a local and virtual international research center and a place of communication between science, politics and business. IZA is an independent, nonprofit limited liability company (Gesellschaft mit beschränkter Haftung) supported by the Deutsche Post AG. The center is associated with the University of Bonn and offers a stimulating research environment through its research networks, research support, and visitors and doctoral programs. IZA engages in (i) original and internationally competitive research in all fields of labor economics, (ii) development of policy concepts, and (iii) dissemination of research results and concepts to the interested public. The current research program deals with (1) mobility and flexibility of labor, (2) internationalization of labor markets, (3) welfare state and labor market, (4) labor markets in transition countries, (5) the future of labor, (6) evaluation of labor market policies and projects and (7) general labor economics.

IZA Discussion Papers often represent preliminary work and are circulated to encourage discussion. Citation of such a paper should account for its provisional character. A revised version may be available on the IZA website (www.iza.org) or directly from the author. 
IZA Discussion Paper No. 646

November 2002

\section{ABSTRACT}

\section{The Return of the Long-Run Phillips Curve}

This paper shows that the interaction between money growth and staggered nominal contracts gives rise to a long-run inflation-unemployment tradeoff.

JEL Classification: E2, E3, E4, E5

Keywords: inflation, unemployment, Phillips curve, nominal inertia, monetary policy, forward-looking expectations

Corresponding author:

Liam Graham

Department of Economics

Birkbeck College

University of London

7 Gresse Street

London W1T 1LL

United Kingdom

Tel.: +44 (20) 76316401

Email: LGraham@econ.bbk.ac.uk 


\footnotetext{
"Most economists who came to accept the view that there was no long-run trade-off between inflation and unemployment were more affected by a priori argument than by empirical evidence." Blanchard and Fisher (1989)
}

\section{Introduction}

The existence of a non-vertical long-run Phillips curve ${ }^{1}$ has long been considered untenable on theoretical grounds. It is generally accepted that, in the absence of money illusion, an increase in the growth rate of the money supply can have real effects only in the short run. In the long run, according to the conventional wisdom, the only effect is an increase in inflation. Our analysis calls this argument into question, without positing any permanent nominal rigidity, any departure from rational expectations or any form of money illusion. We integrate microfoundations of wage staggering into a simple dynamic general equilibrium model with rational expectations. In this context we show that a permanent increase in money growth leads to a permanent increase in the rate of inflation and a permanent reduction in the level of unemployment. In short, we derive a microfounded long-run downward-sloping Phillips curve.

Let us examine the intuition behind this result. Staggered wage setting implies that the current nominal wage is a weighted average of past and expected future nominal wages. A standard result (e.g. Helpmann and Leidermann (1990)) is that the weights on these terms are not symmetric: future wages receive less weight than current ones. If the money supply is growing, this implies that the optimal wage always lags behind the wage that would be chosen under wage flexibility, because more weight is put on past (lower) wages than on current (higher) ones. With prices set as a markup over wages, real money balances are higher than they would be under full wage flexibility. If money growth increases, the optimal wage lags further behind the flexible wage, so that real money balances rise. This raises output and reduces unemployment.

Is this effect likely to be empirically important? We show that, given parameter values that are common in the literature, a $1 \%$ increase in the money growth rate can lead to a long-run decrease in unemployment from $15 \%$ to $0.5 \%$ below its steady state level. In the short and medium run, the effects can be large and have a long half-life.

These results are consonant with a significant body of empirical findings surveyed, for example, in Mankiw (2000) who writes that "..if one does not approach the data with a prior favoring long-run neutrality, one would not leave the data with that posterior. The data's best guess is that monetary shocks leave permanent scars on the economy".

\footnotetext{
${ }^{1}$ By a long-run Phillips curve we mean the long-run relation between inflation and unemployment generated by permanent changes in money growth.
} 


\section{The Model}

We use a dynamic general equilibrium model with the following simplifying assumptions: labor supply is fixed, the production function is linear in labor and there is no capital.

\subsection{Households}

A continuum of households indexed on [0,1] consume, hold money balances and nominal bonds and supply differentiated labor which is imperfectly substitutable (à la Dixit-Stiglitz (1977)) in the production of each firm's output. We make the standard assumption that first the nominal wage is set and then consumption is chosen taking the wage as predetermined.

Each nominal wage is set for two periods, and in each period half of households change their wage. A household $h$ that can change it's wage in period $t$ does so by solving the problem ${ }^{2}$ :

$$
\left.\max _{\mathrm{W}_{t}(h)} E_{t} \sum_{i=0}^{1} \beta^{i} U\left(c_{t+i}(h), \frac{\mathrm{M}_{t+i}}{\mathrm{P}_{t+i}}(h)\right)-V\left(n_{t, t+i}^{d}(h)\right)\right]
$$

(where $\mathrm{W}_{t}(h)$ is the nominal wage, $c_{t+i}(h)$ is consumption, $\beta$ is the time discount factor, and $U_{1}, U_{2}>0, U_{11}, U_{22}<0, V_{1}, V_{11}>0$ ) subject to its budget constraint and the firms' demand curve for the household's labor

$$
n_{t, t+i}^{d}(h)=\left(\frac{\mathrm{W}_{t}(h)}{\mathrm{W}_{t+i}}\right)^{-\theta} n_{t+i}^{d}
$$

Deriving first order conditions, assuming a symmetric equilibrium and linearizing, ${ }^{3}$ we obtain the following equation for the optimal wage, $\hat{W}_{t}^{*}$, chosen by all households that change their price at time t:

$$
\hat{W}_{t}^{*}=\alpha \hat{P}_{t}+(1-\alpha) \hat{P}_{t+1}+(1-\alpha) \hat{\mu}_{t}+\gamma\left[\alpha \hat{y}_{t}+(1-\alpha) \hat{y}_{t+1}\right]
$$

where $\alpha=\frac{1}{1+\beta}$ is a discounting parameter, $\gamma$ is a demand-sensitivity parameter, $\hat{\mu}_{t}$ is the growth rate of the money supply defined by:

$$
\hat{\mu}_{t}=\hat{M}_{t}-\hat{M}_{t-1}
$$

\footnotetext{
${ }^{2}$ In a steady state with money growth, all nominal variables grow at the same rate as money and all real variables are non-trended. We use $\mathrm{X}_{t}$ for a trended variable, $X_{t}$ for a detrended variable, $X$ for the steady state and $\hat{X}$ for the log-linearisation. Upper case letters denote nominal variables, lower case real.

${ }^{3}$ We linearise around a steady state with no money growth.
} 
and $\hat{P}_{t}$ is the linearized Dixit-Stiglitz aggregate price level:

$$
\hat{P}_{t}=\frac{1}{2}\left(\hat{W}_{t-1}^{*}+\hat{W}_{t}^{*}-\hat{\mu}_{t}\right)
$$

Substituting (5) into (3) gives:

$$
\hat{W}_{t}^{*}=\alpha \hat{W}_{t-1}^{*}+(1-\alpha) \hat{W}_{t+1}^{*}-(2 \alpha-1) \hat{\mu}_{t}+\gamma\left[\alpha \hat{y}_{t}+(1-\alpha) \hat{y}_{t+1}\right]
$$

which is a microfounded version of equation (1) in Taylor (1980). Whereas Taylor assumed the coefficients on the backward-looking and forward-looking terms were the same, our derivation is in accord with the standard result that, if the discount factor is less than unity, the backward looking term is weighted more heavily than the forward-looking term. Observe that (6) contains a money growth term $\left(\hat{\mu}_{t}\right)$, which substantiates the intuition given above - namely, that a rise in money growth causes the wage to lag further behind the flexible wage (which is proportional to the money supply), and thus the detrended wage falls $\left(2 \alpha-1>0\right.$ since $\left.\alpha>\frac{1}{2}\right)$.

Given this nominal wage, the representative household ${ }^{4}$ chooses consumption, real money balances and bond holdings by solving the infinite horizon problem:

$$
\left.\max _{\left\{C_{t+j}, \mathrm{M}_{t+j}, \mathrm{~B}_{t+j}\right\}_{j=0}^{\infty}} E_{t} \sum_{i=0}^{\infty} \beta^{i} U\left(c_{t+i} \frac{\mathrm{M}_{t+i}}{\mathrm{P}_{t+i}}\right)-V\left(n^{s}\right)\right]
$$

subject to a series of budget constraints:

$$
\mathrm{P}_{t} c_{t}+\mathrm{M}_{t}+\mathrm{B}_{t}=\mathrm{M}_{t-1}+R_{t} \mathrm{~B}_{t-1}+\mathrm{W}_{t} n^{s}+\mathrm{T}_{t}, \quad \forall t
$$

where $R_{t}$ is the nominal interest rate on bond holdings $\mathrm{B}_{t}$, and $\mathrm{T}_{t}$ is net lump-sum transfers from government.

For the utility function

$$
U\left(c_{t}, \mathrm{M}_{t}\right)=\left[c_{t}^{\gamma}\left(\frac{\mathrm{M}_{t}}{\mathrm{P}_{t}}\right)^{1-\gamma}\right]^{1-\sigma}
$$

the three resulting first-order conditions can be combined to give

$$
c_{t}=\frac{\gamma}{1-\gamma}\left(1-\frac{1}{\beta}\right) \frac{\mathrm{M}_{t}}{\mathrm{P}_{t}}
$$

Detrending and linearizing gives:

$$
\hat{c}_{t}=-\hat{P}_{t}
$$

\footnotetext{
${ }^{4}$ Along standard lines, we assume complete insurance so that equilibrium decisions will be identical across households. For simplicity we have dropped the insurance transfer term from the budget constraint.
} 


\section{$2.2 \quad$ Firms}

Firms face a production function linear in composite labor:

$$
y_{t}=\left[\int_{h^{\prime}=0}^{1} n_{t}\left(h^{\prime}\right)^{\frac{\theta-1}{\theta}} d h^{\prime}\right]^{\frac{\theta}{\theta-1}}
$$

Maximizing profits subject to (12) gives the labour demand curve (2). Linearizing (12) yields $\hat{y}_{t}=\widehat{n}_{t}$. Combining this with the assumption of fixed labor supply, $n^{s}$, we can write unemployment $\left(\hat{u}_{t}=-\nu \hat{n}_{t}\right.$ where $\left.\nu=\frac{n}{n^{s}-n}\right)$ as

$$
\hat{u}_{t}=-\nu \hat{y}_{t}
$$

Then, evaluating the wage equation (6) in the long-run after a money growth shock and using (13), we obtain the long-run Phillips curve:

$$
\hat{\pi}^{L R}=\hat{\mu}^{L R}=-\frac{\nu \gamma}{2 \alpha-1} \hat{u}^{L R}
$$

where inflation is

$$
\hat{\pi}_{t}=\hat{P}_{t}-\hat{P}_{t-1}+\hat{\mu}_{t}
$$

\subsection{General equilibrium}

Since different points on the long-run Phillips curve correspond to different permanent money growth rates, we focus on permanent shocks to money growth. Accordingly, let the money growth rate be a random walk:

$$
\hat{\mu}_{t}=\hat{\mu}_{t-1}+\varepsilon_{t}
$$

where $\varepsilon_{t}$ is a white noise shock.

The government's budget constraint is:

$$
\mathrm{G}_{t}=\mathrm{M}_{t}-\mathrm{M}_{t-1}+\mathrm{B}_{t}-R_{t} \mathrm{~B}_{t-1}-\mathrm{T}_{t}
$$

and we assume that government spending $G_{t}$ is always zero.

Combining (8), (12), and (17) shows that the good market clears, $y_{t}=c_{t}$, and so an equilibrium for this economy is a collection of allocations for households and firms $\left\{\hat{y}_{t}, \hat{M}_{t}\right\}$ together with prices $\left\{\hat{P}_{t}, \hat{W}_{t}^{*}\right\}$ and a money supply process $\left\{\hat{\mu}_{t}\right\}$ that satisfy (4), (5), (6), (11), and (16). We can then use (13) and (15) to obtain unemployment and inflation. This system can be solved explicitly (Karanassou, Sala and Snower (2002)) or simulated using standard methods ${ }^{5}$.

\footnotetext{
${ }^{5}$ MATLAB programs available on request from the authors
} 


\section{Results}

Figure 1 shows the response of the model economy to a change in the growth rate of money from zero to $1 \%$. Calibrating on semi-annual data (so that our assumption of $\mathrm{N}=2$ means wages are fixed for one year), we take the discount factor $\beta$ to be 0.98 . For the demand-sensitivity parameter $\gamma,{ }^{6}$ we use a value of 0.1 and we assume a steady-state level of unemployment of $5 \%$

We find that inflation initially overshoots its long run value $(1 \%$ above its initial value) but falls back to this value within 2 years. Unemployment falls on impact by $8.6 \%$ (relative to its initial steady state) then gradually rises back to its long run level of $2 \%$ below its initial value. In short, unemployment (and of course output) responds strongly to an increase in the rate of money growth and in the long-run unemployment rate remains below its initial value. By contrast, if money were superneutral, the $1 \%$ rise in long-run inflation would leave long-run unemployment unaffected.

Table 1 shows how the magnitude of the real effects depends on the calibrated parameters. Whereas the impact response of unemployment is quite insensitive to plausible parameter variations, this is certainly not the case for the unemployment half-life ${ }^{7}$ of the shock or the slope of the longrun Phillips curve. The higher the discount rate, the more asymmetric are the coefficients in the pricing equation, so the more pronounced is the non-neutrality we describe. As result, the monetary shock has a longer unemployment half-life as well as a larger long-run influence. Decreases in the demand sensitivity parameter $\gamma$ have the same qualitative influence.

Finally, note that the standard New Keynesian Phillips curve, based on the Calvo pricing mechanism, has similar properties, provided that we take discounting seriously. In particular, if the curve is expressed in the standard way $^{8}$ as $\hat{\pi}_{t}-\beta E_{t} \hat{\pi}_{t+1}=-\hat{u}_{t}$, it is clear that a long-run Phillips curve exists here too and for similar reasons - the coefficient on future prices (embedded within future inflation) is larger than that on past prices (embedded within current inflation).

\footnotetext{
${ }^{6}$ Values of between 0.01 and 1 are found in the literature, the bottom end of the range resulting from empirical studies, the top from microfounded models such as our own. Incorporating real rigidities in the microfounded models will, by making wages less responsive to output, bring them in closer agreement with the empirical work.

${ }^{7}$ The time taken for unemployment to reach half-way between the impact response and the new steady state.

${ }^{8}$ See, for example, Walsh (2000), p.219.
} 
Figure 1 : Response of model economy to $1 \%$ increase in rate of money growth

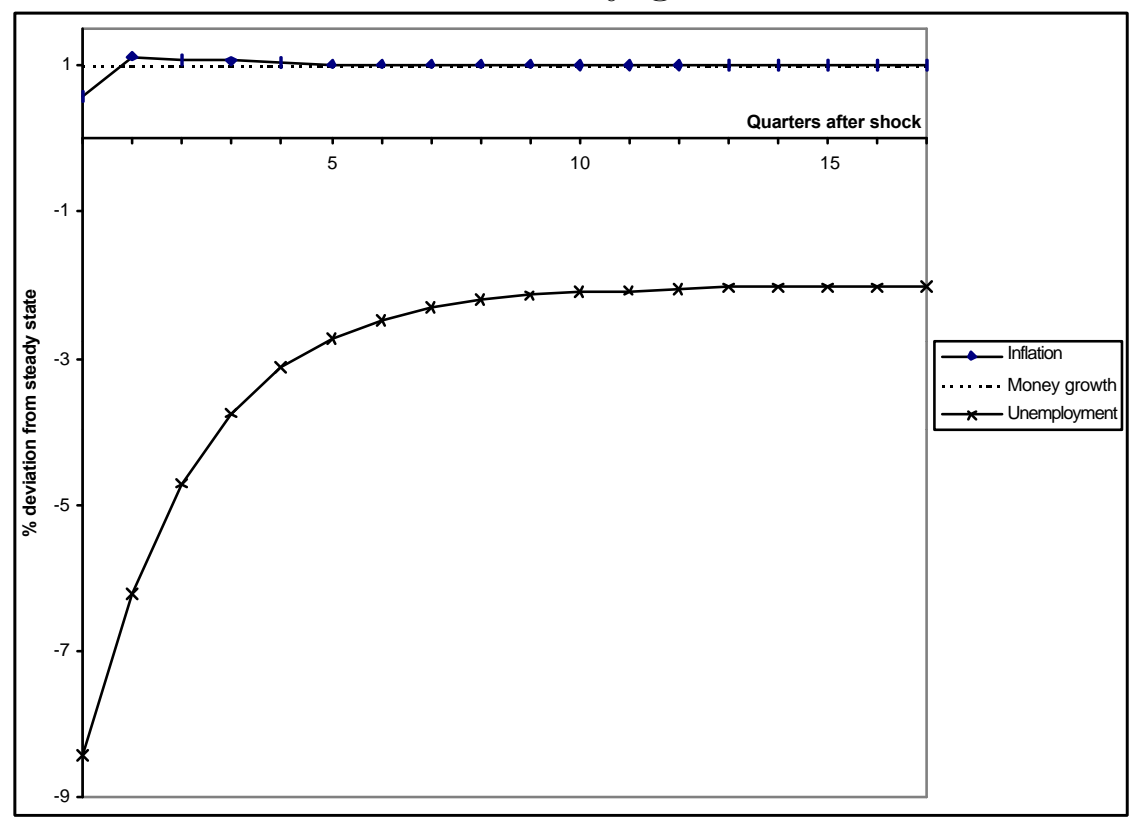

Table 1 : Sensitivity of model economy to calibration

\begin{tabular}{|c|c|c|c|c|c|}
\hline Value of $\gamma$ & 0.02 & 0.05 & 0.1 & 0.2 & 0.3 \\
\hline Long-run response of unemployment $\beta=0.98$ & $-10.1 \%$ & $-4.0 \%$ & $-2.0 \%$ & $-1.0 \%$ & $-0.6 \%$ \\
\hline Impact response of unemployment $\beta=0.98$ & $-10.0 \%$ & $-9.2 \%$ & $-8.6 \%$ & $-7.9 \%$ & $-7.4 \%$ \\
\hline Half-life (6-month periods) $\beta=0.98$ & 5 & 4 & 3 & 2 & 1 \\
\hline Long-run response of unemployment $\beta=0.97$ & $-15.0 \%$ & $-6.1 \%$ & $-3.0 \%$ & $-1.5 \%$ & $-1.0 \%$ \\
\hline Impact response of unemployment $\beta=0.97$ & $-10.4 \%$ & $-9.5 \%$ & $-8.8 \%$ & $-8.0 \%$ & $-7.5 \%$ \\
\hline Half-life (6-month periods) $\beta=0.97$ & 6 & 5 & 4 & 3 & 1 \\
\hline
\end{tabular}




\section{References}

[1] Blanchard, Olivier and Stanley Fisher, 1989, Lectures on macroeconomics, MIT Press, Cambridge, Mass.

[2] Dixit, Avinash K and Joseph E Stiglitz, 1977, Monopolistic competition and optimum product diversity, American Economic Review 67 (3), 297308.

[3] Helpman, Elhanan and Leonardo Leiderman, 1990, Real wages, monetary accommodation and inflation, European Economic Review 34, 897911.

[4] Karanassou, Marika, Hector Sala and Dennis J Snower, 2002, A reappraisal of the inflation-unemployment trade-off, Birkbeck College Working Paper.

[5] Mankiw, Gregory N, 2000, The inexorable and mysterious trade-off between inflation and unemployment, NBER Working paper \# 7884.

[6] Taylor, John, 1980, Aggregate dynamics and staggered contracts, Journal of Political Economy 88 (1), 1-23.

[7] Walsh, Carl, 2000, Monetary Theory and Policy, MIT Press, Cambridge, Mass. 


\title{
Derivations
}

\author{
Liam Graham* and Dennis J. Snower ${ }^{\dagger}$
}

28 October 2002

\section{Notation}

We use the following convention:

\begin{tabular}{|l|l|l|}
\hline & nominal & real \\
\hline trended & $\mathrm{X}_{t}$ & $\mathrm{x}_{t}$ \\
\hline detrended & $X_{t}$ & $x_{t}$ \\
\hline steady state & $X$ & $x$ \\
\hline linearized & $\hat{X}_{t}$ & $\hat{x}_{t}$ \\
\hline
\end{tabular}

If the money supply is growing, the steady state will be one in which nominal variables grow at the same rate as money. In what follows we use both detrended variables, $X_{t}$ and trended variable $\mathrm{X}_{t}$ related by:

$$
X_{t}=\frac{\mathrm{X}_{t}}{\mathrm{M}_{t}}
$$

\section{The Household's Problem}

- households supply differentiated labour and are Dixit-Stiglitz imperfect competitors

- households set $\mathrm{N}$ period wage contracts

- Continuum of households, indexed by h, divided into $\frac{1}{N}$ equal cohorts according to when they can change their wage

- prices are flexible

${ }^{*}$ Department of Economics, Birkbeck College, University of London, 7 Gresse Street, London W1P 2LL, UK; tel: 020 7631-6401; email: LGraham@econ.bbk.ac.uk

${ }^{\dagger}$ Corresponding author : Department of Economics, Birkbeck College, University of London, 7 Gresse Street, London W1P 2LL, UK; tel: 020 7631-6408; email: DSnower@econ.bbk.ac.uk 
Households choose their wage to maximize the present value of their expected future utility. Household h's problem is given by:

$$
\max _{\mathrm{W}_{t}(h)} E_{t} \sum_{i=0}^{N-1} \beta^{i}\left[U\left(c_{t+i}(h)\right)-V\left(l_{t+i}^{d}(h)\right)\right]
$$

subject to series of budget constraints ${ }^{1}$

$$
\mathrm{P}_{t+i} c_{t+i}(h)=\mathrm{W}_{t}(h) l_{t+i}^{d}(h)
$$

and subject to the demand curve for the household's differentiated labour

$$
l_{t, t+i}^{d}(h)=\left(\frac{\mathrm{W}_{t}(h)}{\mathrm{W}_{t+i}}\right)^{-\theta} l_{t+i}^{d}
$$

where $\mathbf{W}_{t}(h)$ is the nominal wage chosen by the household, $\mathbf{W}_{t}$ is a nominal wage index (defined as in Dixit-Stiglitz), and $l_{t}^{d}$ is aggregate labour demand.

Combining the two constraints gives:

$$
c_{t+i}(h)=\frac{\mathrm{W}_{t}(h)}{\mathrm{P}_{t+i}}\left(\frac{\mathrm{W}_{t}(h)}{\mathrm{W}_{t+i}}\right)^{-\theta w} l_{t+i}^{d}
$$

and substituting them into the objective

$$
\max _{\mathrm{W}_{t}(h)} E_{t} \sum_{i=0}^{N-1} \beta^{i}\left[U\left(\frac{\mathrm{W}_{t}(h)}{\mathrm{P}_{t+i}}\left(\frac{\mathrm{W}_{t}(h)}{\mathrm{W}_{t+i}}\right)^{-\theta} l_{t+i}^{d}\right)-V\left(\left(\frac{\mathrm{W}_{t}(h)}{\mathrm{W}_{t+i}}\right)^{-\theta} l_{t+i}^{d}\right)\right]
$$

The first-order condition is:

$$
E_{t} \sum_{i=0}^{N-1} \beta^{i}\left[\left(1-\theta_{w}\right) \frac{l_{t, t+i}^{d}(h)}{\mathrm{P}_{t+i}} U_{c}\left(c_{t+i}(h)\right)+\theta_{w} \frac{l_{t, t+i}^{d}(h)}{\mathrm{W}_{t}(h)} V_{l}\left(l_{t, t+i}^{d}(h)\right)\right]=0
$$

Rearranging:

$\left.E_{t} \sum_{i=0}^{N-1} \beta^{i}\left(1-\theta_{w}\right) \frac{\mathrm{W}_{t}^{*}(h)}{\mathrm{P}_{t+i}} l_{t, t+i}^{d}(h) U_{c}\left(c_{t+i}(h)\right)+\theta_{w} l_{t, t+i}^{d}(h) V_{l}\left(l_{t, t+i}^{d}(h)\right)\right]=0$

\footnotetext{
${ }^{1}$ These combine the household and government budget constraints.
} 
If we wish to linearize around a stationary steady state we need all variables to be stationary. Using (1) we can express the detrend the trended part of this equation as follows:

$$
\begin{aligned}
\frac{\mathrm{W}_{t}^{*}(h)}{\mathrm{P}_{t+i}} & =\frac{W_{t}^{*}(h)}{P_{t+i}} \cdot \frac{\mathrm{M}_{t}}{\mathrm{M}_{t+i}} \\
& =\frac{W_{t}^{*}(h)}{P_{t+i}} \cdot \frac{1}{\mu_{t}^{t+i}}
\end{aligned}
$$

where we define the growth rate of money as:

$$
\mu_{t}=\frac{\mathrm{M}_{t}}{\mathrm{M}_{t-1}}
$$

and write the cumulative growth rate between period $t$ and period $t+i$ as

$$
\mu_{t}^{t+i}=\frac{\mathrm{M}_{t+i}}{\mathrm{M}_{t}}=\frac{1}{\prod_{j=0}^{i-1} \mu_{t+j}}
$$

and we assume that if $\mathrm{i}=0, \prod_{j=1}^{i} \mu_{t+j}=1$. With rational expectiation, if money supply is a random walk we can write:

$$
E_{t} \mu_{t+j}=\mu_{t}
$$

so

$$
E_{t} \mu_{t}^{t+i}=\mu_{t}^{-i}
$$

and

$$
\frac{\mathrm{W}_{t}^{*}(h)}{\mathrm{P}_{t+i}}=\frac{W_{t}^{*}(h)}{P_{t+i}} \mu_{t}^{-i}
$$

Similarly,

$$
\frac{\mathrm{W}_{t}^{*}(h)}{\mathrm{W}_{t+i}}=\frac{W_{t}^{*}(h)}{W_{t+i}} \cdot \mu_{t}^{-i}
$$

So we can rewrite the FOC in terms of detrended variables:

$$
\left.E_{t} \sum_{i=0}^{N-1} \beta^{i}\left(1-\theta_{w}\right) \frac{W_{t}^{*}(h)}{P_{t+i}} \cdot \mu_{t}^{-i} l_{t, t+i}^{d}(h) U_{c}\left(c_{t+i}(h)\right)+\theta_{w} l_{t, t+i}^{d}(h) V_{l}\left(l_{t, t+i}^{d}(h)\right)\right]=0
$$


and rearranging gives:

$$
W_{t}^{*}(h)=\frac{\theta_{w}}{\theta_{w}-1} \frac{E_{t} \sum_{i=0}^{N-1} \beta^{i}\left(-V_{l}\left(l_{t, t+i}^{d}(h)\right)\right) l_{t, t+i}^{d}(h)}{E_{t} \sum_{i=0}^{N-1} \beta^{i} \frac{\mu_{t}^{-i}}{P_{t+i}} U_{c}\left(c_{t+i}(h)\right) l_{t, t+i}^{d}(h)}
$$

In symmetric equilibrium all households able to change their wage at time $\mathrm{t}$ choose the same wage so dropping the household index gives $W_{t}^{*}$ as the optimal wage choice of all households changing their wage at time $\mathrm{t}$ and $l_{t, t+i}^{d}$ the corresponding aggregate labour demand. Then using the production function $y_{t}=l_{t}^{d}$ and goods market clearing $y_{t}=c_{t}$. we can rewrite the FOC as

$$
W_{t}^{*}=\frac{\theta_{w}}{\theta_{w}-1} \frac{E_{t} \sum_{i=0}^{N-1} \beta^{i}\left(-V_{l}\left(y_{t, t+i}\right)\right) y_{t, t+i}}{E_{t} \sum_{i=0}^{N-1} \beta^{i} \frac{\mu_{+}^{-i}}{P_{t+i}} U_{c}\left(y_{t, t+i}\right) y_{t, t+i}}
$$

In the steady -state (dropping time subscripts)

$$
\frac{W^{*}}{P}=\frac{\theta_{w}}{\theta_{w}-1} \frac{\sum_{i=0}^{N-1} \beta^{i}}{\sum_{i=0}^{N-1} \beta^{i} \mu_{t}^{-i}} \cdot\left(\frac{-V_{l}(y)}{U_{c}(y)}\right)
$$

If we consider the case of no steady state money growth this reduces to the familiar markup equation:

$$
\frac{W^{*}}{P}=\frac{\theta_{w}}{\theta_{w}-1}\left(\frac{-V_{l}(y)}{U_{c}(y)}\right)
$$

i.e. the real wage is set as a markup over the marginal disutility of labour expressed in terms of consumption, and the markup decreases as the labour types become better substitutes. For perfect substitutes $\left(\theta_{w}=\infty\right)$ the markup is unity.

\section{Linearization}

Rewrite (19) as (dropping the expectations operator to save notation)

$$
W_{t}^{*} \sum_{i=0}^{N-1} \beta^{i} \frac{\mu_{t}^{-i}}{P_{t+i}} U_{c}\left(y_{t, t+i}\right) y_{t, t+i}=\frac{\theta_{w}}{\theta_{w}-1} \sum_{i=0}^{N-1} \beta^{i}\left[-V_{l}\left(\left(\frac{W_{t}^{*}}{W_{t+i}} \mu_{t}^{-i}\right)^{-\theta_{w}} y_{t+i}\right)\right] y_{t, t+i}
$$


Linearizing the LHS:

$$
\frac{W^{*} y U_{c}(y)}{P} \sum_{i=0}^{N-1} \beta^{i} \mu^{-i}\left[\hat{W}_{t}^{*}-\hat{P}_{t+i}-i \hat{\mu}_{t}+\hat{y}_{t, t+i}\left(1+\xi_{c}\right)\right]
$$

Linearizing the RHS:

$$
\frac{\theta_{w}}{\theta_{w}-1} y\left(-V_{l}(y)\right) \sum_{i=0}^{N-1} \beta^{i}\left[\hat{y}_{t, t+i}+\xi_{l}\left(\hat{y}_{t, t+i}-\theta_{w}\left(\hat{W}_{t}^{*}-\hat{W}_{t+i}+i \hat{\mu}_{t}\right)\right)\right]
$$

where

$$
\xi_{c}=\frac{c U_{c c}(c)}{U_{c}(c)} \text { and } \xi_{l}=\frac{l V_{l l}(l)}{V_{l}(l)}
$$

Equating (23) with (24) and using (21) to simplify

$$
\begin{aligned}
& \sum_{i=0}^{N-1} \beta^{i} \mu^{-i}\left[\hat{W}_{t}^{*}-\hat{P}_{t+i}-i \hat{\mu}_{t}+\hat{y}_{t, t+i}\left(1+\xi_{c}\right)\right]= \\
& \cdot \sum_{i=0}^{N-1} \beta^{i} \hat{y}_{t, t+i}^{i}\left[\hat{y}_{t, t+i}+\xi_{l}\left(\hat{y}_{t, t+i}-\theta_{w}\left(\hat{W}_{t}^{*}-\hat{W}_{t+i}+i \hat{\mu}_{t}\right)\right)\right]
\end{aligned}
$$

Rearranging

$$
\begin{aligned}
\sum_{i=0}^{N-1} \beta^{i} \mu^{-i} \hat{W}_{t}^{*}= & \sum_{i=0}^{N-1} \beta^{i}\left[\hat{y}_{t, t+i}+\xi_{l}\left(\hat{y}_{t, t+i}-\theta_{w}\left(\hat{W}_{t}^{*}-\hat{W}_{t+i}+i \hat{\mu}_{t}\right)\right)\right]+ \\
& \sum_{i=0}^{N-1} \beta^{i} \mu^{-i}\left[\hat{P}_{t+i}+i \hat{\mu}_{t}-\hat{y}_{t, t+i}\left(1+\xi_{c}\right)\right] \\
\sum_{i=0}^{N-1} \beta^{i}\left(\mu^{-i}+\xi_{l} \theta_{w}\right) \hat{W}_{t}^{*}= & \sum_{i=0}^{N-1} \beta^{i}\left[\hat{y}_{t, t+i}+\xi_{l}\left(\hat{y}_{t, t+i}+\theta_{w}\left(\hat{W}_{t+i}+i \hat{\mu}_{t}\right)\right)\right]+ \\
& \sum_{i=0}^{N-1} \beta^{i} \mu^{-i}\left[\hat{P}_{t+i}+i \hat{\mu}_{t}-\hat{y}_{t, t+i}\left(1+\xi_{c}\right)\right]
\end{aligned}
$$

In the case of no steady state money growth $\mu=1$ this reduces to

$$
\hat{W}_{t}^{*}=\frac{1}{\left(1+\xi_{l} \theta_{w}\right) \sum_{i=0}^{N-1} \beta^{i}}\left[\sum_{i=0}^{N-1} \beta^{i}\left(\hat{P}_{t+i}+\xi_{l} \theta_{w} \hat{W}_{t+i}+\left(1+\xi_{l} \theta_{w}\right) i \hat{\mu}_{t}\right)+\left(\xi_{l}+\xi_{c}\right) \sum_{i=0}^{N-1} \beta^{i} \hat{y}_{t, t+i}\right]
$$


Prices are flexible so are set as a constant markup over the wage which means $\hat{P}_{t+i}=\hat{W}_{t+i}$ and we can write

$$
\hat{W}_{t}^{*}=\frac{1}{\sum_{i=0}^{N-1} \beta^{i}}\left[\sum_{i=0}^{N-1} \beta^{i}\left(\hat{W}_{t+i}+i \hat{\mu}_{t}\right)+\gamma \sum_{i=0}^{N-1} \beta^{i} \hat{y}_{t, t+i}\right]
$$

where

$$
\gamma=\frac{\xi_{l}+\xi_{c}}{1+\xi_{l} \theta_{w}}
$$

And if we consider the case $\mathrm{N}=2$ the household's wage setting equation is:

$$
\hat{W}_{t}^{*}=\alpha \hat{W}_{t}+(1-\alpha) \hat{W}_{t+1}+(1-\alpha) \hat{\mu}_{t}+\gamma\left[\alpha \hat{y}_{t}+(1-\alpha) \hat{y}_{t+1}\right]
$$

or in terms of the price level

$$
\hat{W}_{t}^{*}=\alpha \hat{P}_{t}+(1-\alpha) \hat{P}_{t+1}+(1-\alpha) \hat{\mu}_{t}+\gamma\left[\alpha \hat{y}_{t}+(1-\alpha) \hat{y}_{t+1}\right]
$$

The aggregate wage level is given by

$$
\mathrm{W}_{t}=\left(\int_{o}^{1} \mathrm{~W}_{t}(h)^{1-\sigma} d h\right)^{\frac{1}{1-\sigma}}
$$

With $\mathrm{N}$ cohorts of households each choosing their optimal wage this is:

$$
\mathrm{W}_{t}=\left(\frac{1}{N} \sum_{i=0}^{N-1} \mathrm{~W}_{t-i}^{*} 1-\sigma\right)^{\frac{1}{1-\sigma}}
$$

Writing this in terms of detrended wages gives:

$$
\begin{aligned}
W_{t} & =\left(\sum_{i=0}^{N-1}\left(W_{t-i}^{*} \frac{\mathrm{M}_{t-i}}{\mathrm{M}_{t}}\right)^{1-\sigma}\right)^{\frac{1}{1-\sigma}} \\
& =\left(\sum_{i=0}^{N-1}\left(W_{t-i}^{*} \mu_{t-i}^{t}\right)^{1-\sigma}\right)^{\frac{1}{1-\sigma}}
\end{aligned}
$$

Consider case $\mathrm{N}=2$ :

$$
W_{t}=\left(W_{t}^{* 1-\sigma}+\left(\frac{1}{\mu_{t}} W_{t-1}^{*}\right) 1-\sigma\right)^{\frac{1}{1-\sigma}}
$$


Linearizing:

$$
\begin{aligned}
\hat{W}_{t} & =\frac{W^{1-\sigma}\left(\hat{W}_{t}^{*}+\mu^{\sigma-1}\left(\hat{W}_{t-1}^{*}-\frac{1}{\mu} \hat{\mu}_{t}\right)\right)}{W^{1-\sigma}+\left(\frac{1}{\mu} W\right)^{1-\sigma}} \\
& =\frac{\hat{W}_{t}^{*}+\mu^{\sigma-1}\left(\hat{W}_{t-1}^{*}-\frac{1}{\mu} \hat{\mu}_{t}\right)}{1+\mu^{\sigma-1}}
\end{aligned}
$$

Around the steady state with no money growth $\mu=1$ this simplifies to:

$$
\hat{W}_{t}=\frac{1}{2}\left(\hat{W}_{t}^{*}+\hat{W}_{t-1}^{*}-\hat{\mu}_{t}\right)
$$

Substituting this into (32) gives (dropping the terms in output for simplicity):

$$
\begin{aligned}
\hat{W}_{t}^{*} & =\frac{\alpha}{2}\left(\hat{W}_{t}^{*}+\hat{W}_{t-1}^{*}-\hat{\mu}_{t}\right)+\frac{1-\alpha}{2}\left(\hat{W}_{t+1}^{*}+\hat{W}_{t}^{*}-\hat{\mu}_{t}\right)+(1-\alpha) \hat{\mu}_{t}(42) \\
& =\frac{1}{2} \hat{W}_{t}^{*}+\frac{1}{2}\left[\alpha \hat{W}_{t-1}^{*}+(1-\alpha) \hat{W}_{t+1}^{*}+(1-2 \alpha) \hat{\mu}_{t}\right] \\
& =\alpha \hat{W}_{t-1}^{*}+(1-\alpha) \hat{W}_{t+1}^{*}+(1-2 \alpha) \hat{\mu}_{t}
\end{aligned}
$$

So the household's linearized wage setting equation is:

$$
\hat{W}_{t}^{*}=\alpha \hat{W}_{t-1}^{*}+(1-\alpha) \hat{W}_{t+1}^{*}-(2 \alpha-1) \hat{\mu}_{t}+\gamma\left[\alpha \hat{y}_{t}+(1-\alpha) \hat{y}_{t+1}\right]
$$

\section{Household consumption decision}

The representative household chooses consumption, real money balances and bond holdings by solving the infinite horizon problem:

$$
\max _{\left\{C_{t+j}, \mathrm{M}_{t+j}, \mathrm{~B}_{t+j}\right\}_{j=0}^{\infty}} E_{t} \sum_{i=0}^{\infty} \beta^{i}\left[U\left(c_{t+i}, \mathrm{M}_{t+i}\right)-V(L)\right]
$$

subject to a series of budget constraints:

$$
\mathrm{P}_{t} c_{t}+\mathrm{M}_{t}+\mathrm{B}_{t}=\mathrm{M}_{t-1}+i_{t} \mathrm{~B}_{t-1}+\mathrm{W}_{t} L
$$

Considering a utility function

$$
U\left(c_{t}, \mathrm{M}_{t}\right)=\left[c_{t+i}^{\gamma}\left(\frac{\mathrm{M}_{t+i}}{\mathrm{P}_{t+i}}\right)^{1-\gamma}\right]^{1-\sigma}
$$


The first order conditions are:

$$
\begin{aligned}
c_{t} & : \quad U_{c}=\mathrm{P}_{t} \lambda_{t} \\
\frac{\mathrm{M}_{t}}{\mathrm{P}_{t}} & : \quad U_{\frac{\mathrm{M}}{\mathrm{P}}}=\mathrm{P}_{t} \lambda_{t}-\mathrm{P}_{t+1} \lambda_{t+1} \\
\mathrm{~B}_{t} & : \quad U_{\mathrm{B}}=\lambda_{t}-i_{t+1} \lambda_{t+1}
\end{aligned}
$$

Considering a utility function

$$
U\left(c_{t}, \mathrm{M}_{t}\right)=\left[c_{t+i}^{\gamma}\left(\frac{\mathrm{M}_{t+i}}{\mathrm{P}_{t+i}}\right)^{1-\gamma}\right]^{1-\sigma}
$$

gives

$$
\begin{aligned}
c_{t} & : \frac{\gamma \cdot(1-\sigma)}{c_{t}}\left[c_{t}^{\gamma}\left(\frac{\mathrm{M}_{t}}{\mathrm{P}_{t}}\right)^{1-\gamma}\right]^{1-\sigma}=\mathrm{P}_{t} \lambda_{t} \\
\mathrm{M}_{t} & : \frac{(1-\gamma) \cdot(1-\sigma)}{\mathrm{M}_{t} / \mathrm{P}_{t}}\left[c_{t}^{\gamma}\left(\frac{\mathrm{M}_{t}}{\mathrm{P}_{t}}\right)^{1-\gamma}\right]^{1-\sigma}=\mathrm{P}_{t} \lambda_{t}-\mathrm{P}_{t+1} \lambda_{t+1} \\
\mathrm{~B}_{t} & : 0=\lambda_{t}-i_{t+1} \lambda_{t+1}
\end{aligned}
$$

Using (55) to substitute for $\lambda_{t+1}$ in (54) gives:

$$
\frac{(1-\gamma) \cdot(1-\sigma)}{\mathrm{M}_{t}}\left[c_{t}^{\gamma}\left(\frac{\mathrm{M}_{t}}{\mathrm{P}_{t}}\right)^{1-\gamma}\right]^{1-\sigma}=\lambda_{t}\left(1-\frac{\mathrm{P}_{t+1}}{\mathrm{P}_{t}} \frac{1}{i_{t+1}}\right)
$$

and define the real interest rate:

$$
r_{t+1}=\frac{\mathrm{P}_{t+1}}{\mathrm{P}_{t}} \frac{1}{i_{t+1}}
$$

and substituting for $\lambda_{t}$ from (53)

$$
c_{t}=\frac{\gamma}{(1-\gamma)} \frac{\mathrm{M}_{t}}{\mathrm{P}_{t}}\left(1-\frac{1}{r_{t+1}}\right)
$$

Without capital the real interest rate will be constant and equal to $\frac{1}{\beta}$ 


\section{IZA Discussion Papers}

\begin{tabular}{|c|c|c|c|c|}
\hline No. & Author(s) & Title & Area & Date \\
\hline 630 & W. Arulampalam & $\begin{array}{l}\text { State Dependence in Unemployment Incidence: } \\
\text { Evidence for British Men Revisited }\end{array}$ & 3 & $11 / 02$ \\
\hline 631 & $\begin{array}{l}\text { H. O. Duleep } \\
\text { M. Regets }\end{array}$ & $\begin{array}{l}\text { The Elusive Concept of Immigrant Quality: } \\
\text { Evidence from 1970-1990 }\end{array}$ & 1 & $11 / 02$ \\
\hline 632 & $\begin{array}{l}\text { B. Cockx } \\
\text { M. Dejemeppe }\end{array}$ & $\begin{array}{l}\text { Duration Dependence in the Exit Rate out of } \\
\text { Unemployment in Belgium: Is It True or } \\
\text { Spurious? }\end{array}$ & 2 & $11 / 02$ \\
\hline 633 & A. D. Kugler & Employee Referrals and Efficiency Wages & 5 & $11 / 02$ \\
\hline 634 & $\begin{array}{l}\text { A. D. Kugler } \\
\text { R. M. Sauer }\end{array}$ & $\begin{array}{l}\text { Doctors Without Borders: The Returns to an } \\
\text { Occupational License for Soviet Immigrant } \\
\text { Physicians in Israel }\end{array}$ & 1 & $11 / 02$ \\
\hline 635 & $\begin{array}{l}\text { M. Karanassou } \\
\text { D. J. Snower }\end{array}$ & An Anatomy of the Phillips Curve & 3 & $11 / 02$ \\
\hline 636 & $\begin{array}{l}\text { M. Karanassou } \\
\text { H. Sala } \\
\text { D. J. Snower }\end{array}$ & $\begin{array}{l}\text { A Reappraisal of the Inflation-Unemployment } \\
\text { Tradeoff }\end{array}$ & 3 & $11 / 02$ \\
\hline 637 & $\begin{array}{l}\text { H. Bonin } \\
\text { W. Kempe } \\
\text { H. Schneider }\end{array}$ & $\begin{array}{l}\text { Household Labor Supply Effects of Low-Wage } \\
\text { Subsidies in Germany }\end{array}$ & 3 & $11 / 02$ \\
\hline 638 & $\begin{array}{l}\text { L. McLeod } \\
\text { M. R. Veall }\end{array}$ & $\begin{array}{l}\text { The Dynamics of Food Deprivation and Overall } \\
\text { Health: Evidence from the Canadian National } \\
\text { Population Health Survey }\end{array}$ & 2 & $11 / 02$ \\
\hline 639 & G. Saint-Paul & Are Intellectual Property Rights Unfair? & 3 & $11 / 02$ \\
\hline 640 & $\begin{array}{l}\text { J. Hartog } \\
\text { N. Jonker } \\
\text { H. van Ophem }\end{array}$ & $\begin{array}{l}\text { Dual Track or Academic Route for Auditors: } \\
\text { Does It Matter? }\end{array}$ & 6 & $11 / 02$ \\
\hline 641 & $\begin{array}{l}\text { J. Hartog } \\
\text { L. Diaz Serrano }\end{array}$ & $\begin{array}{l}\text { Earning Risk and Demand for Higher Education: } \\
\text { A Cross-Section Test for Spain }\end{array}$ & 2 & $11 / 02$ \\
\hline 642 & $\begin{array}{l}\text { J. Hartog } \\
\text { A. Zorlu }\end{array}$ & $\begin{array}{l}\text { The Effect of Immigration on Wages in Three } \\
\text { European Countries }\end{array}$ & 1 & $11 / 02$ \\
\hline 643 & $\begin{array}{l}\text { A. Björklund } \\
\text { M. Sundström }\end{array}$ & $\begin{array}{l}\text { Parental Separation and Children's Educational } \\
\text { Attainment: A Siblings Approach }\end{array}$ & 6 & $11 / 02$ \\
\hline 644 & $\begin{array}{l}\text { J. D. Brown } \\
\text { J. S. Earle }\end{array}$ & $\begin{array}{l}\text { Job Reallocation and Productivity Growth Under } \\
\text { Alternative Economic Systems and Policies: } \\
\text { Evidence from the Soviet Transition }\end{array}$ & 4 & $11 / 02$ \\
\hline 645 & $\begin{array}{l}\text { M. Karanassou } \\
\text { H. Sala } \\
\text { D. J. Snower }\end{array}$ & $\begin{array}{l}\text { Long-Run Inflation-Unemployment Dynamics: } \\
\text { The Spanish Phillips Curve and Economic Policy }\end{array}$ & 3 & $11 / 02$ \\
\hline 646 & $\begin{array}{l}\text { L. Graham } \\
\text { D. Snower }\end{array}$ & The Return of the Long-Run Phillips Curve & 3 & $11 / 02$ \\
\hline
\end{tabular}

An updated list of IZA Discussion Papers is available on the center's homepage www.iza.org. 